\section{Detection of human papillomavirus in pterygium and conjunctival papilloma by hybrid capture II and PCR assays}

Y Takamura, E Kubo, S Tsuzuki and Y Akagi

Department of

Ophthalmology, Faculty of Medical Sciences, University of Fukui, Eiheiji-cho, Yoshida-gun, Fukui-ken, Japan

Correspondence: Y Akagi, Department of Ophthalmology, Faculty of Medical Sciences, University of Fukui,

Eiheiji-cho,

Yoshida-gun, Fukui-ken

910-1193, Japan

Tel: + 8177661 8403;

Fax: + 81776618131

E-mail: akagiy@

u-fukui.ac.jp

Received: 21 February 2008 Accepted in revised form: 10 May 2008

Published online: 6 June 2008

\begin{abstract}
Aim To elucidate the putative role of human papillomavirus (HPV) infection in pterygium and conjunctival papilloma.

Methods Hybrid capture II (HC-II) and polymerase chain reaction (PCR) assays were performed to detect HPV in pterygium (42 samples obtained from 40 patients) and conjunctival papilloma (8 samples from 6 patients). The amount of HPV DNA was evaluated by measurement of relative light units (RLUs) on a luminometer.

Results All papilloma samples were positive for HPV DNA by PCR and HC-II. The RLU values for specimens of recurrent and re-recurrent papilloma were markedly higher than those for specimens of primary lesions. HPV was detected by PCR in 2 of 42 (4.8\%) $\beta$-globin-positive pterygium specimens, whereas HC-II showed that HPV was negative in all pterygium samples.

Conclusions Our results support the hypothesis that HPV DNA is associated with the pathogenesis of conjunctival papilloma, but not pterygium. RLU measurement by HC-II may serve as a marker for evaluating the activity of HPV in conjunctival tumours. Eye (2008) 22, 1442-1445; doi:10.1038/eye.2008.176; published online 6 June 2008
\end{abstract}

Keywords: human papillomavirus; pterygium; papilloma; PCR; hybrid capture assay; HC-II

\section{Introduction}

Pterygium and papilloma are benign conjunctival tumours that can be treated by surgical excision. However, recurrences are frequently observed, and recurrent lesions tend to grow more rapidly than primary lesions. ${ }^{1}$ Thus, it is important to clarify the mechanisms of development of these lesions. Although the aetiology of pterygium and papilloma has not been established, human papillomavirus (HPV) is thought to be one of the causative factors..$^{2-5}$

HPV is a family of double-stranded circular DNA viruses, of which more than 80 types have been identified. ${ }^{6} \mathrm{HPV}$ s have oncogenic potential and contribute to the progression of neoplastic conditions. HPV DNA has been detected in papillomas, dysplasia, and cancers in the cornea and conjunctiva. ${ }^{7}$ The association of HPV with the pathogenesis of conjunctival papilloma is well established, as many investigators have demonstrated the presence of HPV DNA in conjunctival papilloma using polymerase chain reaction (PCR). ${ }^{8,9}$ Also, several studies have shown that HPV DNA can be detected in pterygium by PCR. ${ }^{3,10,11}$ However, the proportion of cases that are positive for HPV DNA shows marked variation; HPV DNA has been detected in up to $50 \%$ cases of pterygium, whereas other studies have failed to detect any. ${ }^{12}$ Therefore, the involvement of HPV in the pathogenesis of pterygium remains controversial.

To address this issue, we attempted to measure the amount of HPV DNA in conjunctival papilloma and pterygium. The second-generation hybrid capture (HC-II) assay is a non-radioactive, reproducible, relatively rapid liquid hybridization assay, with a sensitivity similar to that of PCR. ${ }^{13,14}$ It is based on the measurement of relative light units (RLUs) as a semiquantitative index of the amount of HPV DNA. ${ }^{15}$ Some previous studies 
have shown that the RLU level is correlated positively with disease severity. ${ }^{16}$ As studies of conjunctival papilloma using PCR have revealed a high rate of HPV detection, it is probable that this lesion is suitable for investigation by HC-II to clarify the magnitude of the RLU value, which would provide further information for clarifying the role of HPV in its pathogenesis. In the present study, we applied the HC-II assay for detection of HPV DNA in conjunctival pterygium and papilloma, and evaluated the possible correlation between the amount of HPV DNA and the clinical profile of these conjunctival tumours.

\section{Polymerase chain reaction}

Formalin-fixed paraffin blocks were incubated with $200 \mu \mathrm{g} / \mathrm{ml}$ proteinase $\mathrm{K}$ in $10 \mathrm{~mm}$ Tris ( $\mathrm{pH} 7.0$ ) $-1 \mathrm{~mm}$ EDTA at $65^{\circ} \mathrm{C}$ for $3 \mathrm{~h}$, spun, and the supernatant was used for PCR assay. Primers for a fragment of the $\beta$-globin gene served as an initial control to assess the quality and quantity of the template DNA. To detect the presence of HPV DNA, PCR was performed with the generally accepted consensus GP5 + /GP6 + primers. $^{17}$ The samples were heated at $95^{\circ} \mathrm{C}$ for $4 \mathrm{~min}$, followed by 40 cycles of amplification: denaturation at $94^{\circ} \mathrm{C}$ for $1 \mathrm{~min}$, annealing at $40^{\circ} \mathrm{C}$ for $2 \mathrm{~min}$, and extension at $72^{\circ} \mathrm{C}$ for $1.5 \mathrm{~min}$. A $15 \mu \mathrm{l}$ volume of the PCR product was run in a $2 \%$ agarose gel, and stained with ethidium bromide.

\section{Hybrid capture assay II}

Surgically obtained samples were immediately and directly subjected to HC-II system (Digene, Gaithersburg, MD, USA) and assayed in accordance with the manufacture's instruction manual. This assay is based on sandwich hybridization followed by a non-radioactive alkaline phosphatase reaction with chemoluminescence using microplates supplied the HC-II kit. RLUs were calculated as follows: LU of sample/LU of positive control. The standard cut-off point (1 RLU) was considered positive for the presence of HPV DNA. HPV-11 and -16 DNA ( $1 \mathrm{pg} / \mathrm{ml}$ each) were used as a positive control for both low- and high-risk probes, respectively.

\section{Results}

The $\beta$-globin fragment was amplified by PCR in all of the 47 specimens (42 cases of pterygium and 7 cases of gave their consent for use of their tissue samples.

Table 1 Details of specimens used

\begin{tabular}{|c|c|c|c|c|c|c|c|c|}
\hline \multirow[t]{2}{*}{ Diagnosis } & \multirow[t]{2}{*}{ Patient number } & \multirow[t]{2}{*}{ Specimen type } & \multirow[t]{2}{*}{ Age (years) } & \multirow[t]{2}{*}{$\operatorname{Sex}$} & \multicolumn{2}{|c|}{$H P V$ detection } & \multicolumn{2}{|c|}{ RLUs measured by HC-II } \\
\hline & & & & & PCR & $H C-I I$ & Low-risk & High-risk \\
\hline \multirow[t]{8}{*}{ Papilloma } & 1 & Primary & 76 & M & $(+)$ & $(+)$ & 1.1 & 0.18 \\
\hline & 2 & Primary & 28 & M & $(+)$ & $(+)$ & 151.3 & 0.94 \\
\hline & 3 & Primary & 42 & $\mathrm{~F}$ & $(+)$ & $(+)$ & 8.3 & 0.35 \\
\hline & 4 & Primary & 39 & M & $(+)$ & $(+)$ & 9.8 & 0.44 \\
\hline & 5 & Primary & 41 & $\mathrm{~F}$ & $(+)$ & $(+)$ & 3.4 & 0.23 \\
\hline & 6 & Primary & 38 & M & $(+)$ & $(+)$ & 2.1 & 0.14 \\
\hline & 6 & Recurrence & & & $(+)$ & $(+)$ & 50.4 & 0.21 \\
\hline & 6 & Re-recurrence & & & $(+)$ & $(+)$ & 242.3 & 0.98 \\
\hline \multirow[t]{5}{*}{ Pterygium } & 1 & Primary & 73 & $\mathrm{~F}$ & $(+)$ & $(-)$ & 0.13 & 0.11 \\
\hline & 2 & Primary & 42 & M & $(+)$ & $(-)$ & 0.19 & 0.14 \\
\hline & $3-40$ & Primary & & & $(-)$ & $(-)$ & $<1.0$ & $<1.0$ \\
\hline & 41 & Recurrence & 49 & $\mathrm{~F}$ & $(-)$ & $(-)$ & 0.09 & 0.10 \\
\hline & 42 & Recurrence & 71 & M & $(-)$ & $(-)$ & 0.14 & 0.16 \\
\hline
\end{tabular}

$\mathrm{HC}-\mathrm{II}=$ hybrid capture assay II; PCR = polymerase chain reaction; RLUs = relative light units. 


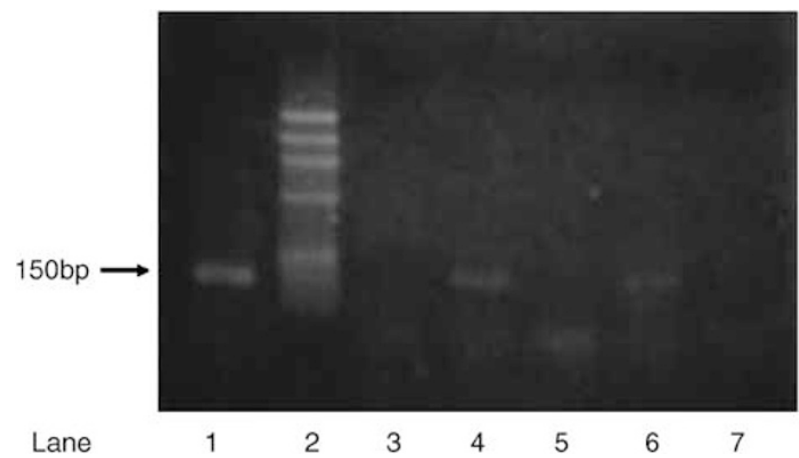

Figure 1 Electrophoresis of PCR products on 2\% agarose gel (150 bp sequence of the HPV L1 gene). Lanes 1 and 4 are specimens positive for papilloma (case 1, recurrent and primary lesions, respectively); lane 2, DNA marker; lane 6, HPV-positive specimen of pterygium; lanes 3, 5, and 7, HPV-negative specimens of pterygium.

papilloma). The profiles of the patients and the incidences of HPV in the specimens examined by PCR and HC-II are shown in Table 1. HPV DNA (150 bp) was detected in 2 of the $42(4.8 \%)$ pterygium specimens and in all conjunctival papilloma samples (Figure 1). HC-II assay showed that the primary papilloma specimen was positive for low-risk-type HPV; the RLU values for cases $1,2,3,4,5$, and 6 were 1.1, 151.3, 8.3, 9.8, 3.4, and 2.1, respectively. In case 2 showing high RLU values, the tumour developed rapidly during 1 month, whereas the primary lesion in other cases showed no progression at least for 1 year preoperatively. The recurrent and re-recurrent papilloma specimens taken from case 6 were strongly positive (RLU values 50.4 and 242.3,

respectively). All papilloma samples including those from primary and recurrent lesions were negative for high-risk HPV $(<1.0)$. HC-II gave negative results $(<1.0)$ for low- or high-risk-type HPV DNA in all the pterygium specimens.

\section{Discussion}

Previous studies have shown good agreement between the results of HC-II and PCR for detection of HPV in premalignant and malignant cervical lesions, and therefore both techniques are considered to be useful for the screening of HPV DNA in these lesions. ${ }^{18}$ Similarly, we successfully detected HPV DNA using PCR and HC-II assays in all specimens of conjunctival papilloma. Recently, Sjö et $a l^{9}$ reported that PCR gave positive results for HPV in 86 (81\%) of 106 papilloma specimens studied. In addition, HPV was detected in all five papilloma cases studied by Saegusa et al, ${ }^{19}$ and in 9 of 10 papilloma cases (90\%) studied by Gallagher et al. ${ }^{3}$ The presence of HPV in papilloma has also been confirmed by Southern blotting and in situ hybridization. ${ }^{20}$ Based on these reports and our data, it is likely that HPV is closely involved in the pathogenesis of conjunctival papillomas.

One of the advantages of HC-II is its ability to estimate viral genome copy number from the magnitude of the RLU value obtained. ${ }^{14,15}$ As the RLU value reflects the activity of HPV, it may be closely associated with the progression of papilloma. ${ }^{15}$ In fact, our HC-II data showed that the RLU values in recurrent and re-recurrent papilloma specimens were 25 times and 115 times higher, respectively, than in the primary specimen. Moreover, one primary case with severe progression showed extremely high RLU values. Based on our results, we propose that HC-II may be useful for the detection of HPV and evaluation of its activity in conjunctival disease.

In contrast, HPV DNA was not detected in any of the pterygium samples by HC-II assay. The results of PCR assay also showed that $95.2 \%$ of pterygium cases were HPV-negative. The low copy number of the HPV genome suggests that the amount of HPV DNA in pterygium is very low. Two recurrent cases of pterygium were negative for HPV DNA by both HC-II and PCR assays. Also, two pterygium cases that were HPV-positive by PCR showed a normal growth pattern with no aggressive features. On the other hand, the RLU values for papillomas showing aggressive growth (case 2) or recurrence (case 6) were markedly high. These results suggest that the amount of HPV reflects the clinical profile of papilloma, whereas this is not the case for pterygium.

Previous studies have shown a wide variation in the detection rate of HPV DNA in pterygium. A recent study has suggested that one possible explanation might be the geographical differences in the frequency of HPV involvement in pterygium. ${ }^{4}$ However, in an investigation of a large number of pterygium cases, Sjö $e t a l^{9}$ concluded that the low presence of HPV $(4 / 90 ; 4.4 \%)$ detected by PCR does not support the hypothesis that HPV is involved in the development of pterygium. Our data agree with this finding, and suggest that the level of HPV DNA in pterygium is low, implying that the presence of HPV is insufficient for the development of this tumour. As PCR analysis is very sensitive, it detects HPV even when present in tiny amounts, and, in fact, Sjö et al ${ }^{11}$ have also shown that all pterygium cases that were HPV-positive by PCR were negative by in situ hybridization. The development of pterygium may be initiated synergistically by other causative factors, such as chronic exposure to ultraviolet radiation, concomitant infection with herpes virus, and disruption of apoptosis. ${ }^{5,10,12}$

In conclusion, our data suggest that there is a strong association between HPV and conjunctival papilloma, but not pterygium. As the RLU value was linked to the 
clinical profile of conjunctival papilloma, HC-II may be a useful tool for monitoring the activity of HPV in conjunctival tumours.

\section{References}

1 Allan BD, Short P, Crawford GJ, Barrett GD, Constable IJ. Pterygium excision with conjunctival autografting: an effective and safe technique. Br J Ophthalmol 1993; 77: 698-701.

2 Coroneo MT. Pterygium as an indicator of ultraviolet insulation: a hypothesis. Br J Ophthalmol 1993; 77: 734-739.

3 Gallagher MJ, Giannoudis A, Herrington CS, Hiscott P. Human papillomavirus in pterygium. Br J Ophthalmol 2001; 85: 782-784.

4 Piras F, Moore PS, Ugalde J, Perra MT, Scarpa A, Sirigu P. Detection of human papillomavirus DNA in pterygia from different geographical regions. $\mathrm{Br}$ J Ophthalmol 2003; 87: 864-866.

5 Tan DT, Tang WY, Liu YP, Goh HS, Smith DR. Apoptosis and apoptosis related gene expression in normal conjunctiva and pterygium. Br J Ophthalmol 2000; 84: 212-216.

6 Zur Hausen H. Papillomavirus infections: a major cause of human cancers. Biochim Biophys Acta 1996; 1288: 55-78.

7 McDonnell JM, Mayr AJ, Martin WJ. DNA of human papillomavirus type 16 in dysplastic and malignant lesions of the conjunctiva and cornea. N Engl J Med 1989; 320: $1442-1446$.

8 Sjö NC, Heegaard S, Prause JU. Human papillomavirus in conjunctival papilloma. Br J Ophthalmol 2001; 85: 785-787.

9 Sjö NC, von Buchwald C, Cassonnet P, Norrild B, Prause JU, Vinding $\mathrm{T}$ et al. Human papillomavirus in normal conjunctival tissue and in conjunctival papilloma: types and frequencies in a large series. Br J Ophthalmol 2007; 91: 1014-1015.

10 Detorakis ET, Sourvinos G, Spandidos DA. Detection of herpes simplex virus and human papilloma virus in ophthalmic pterygium. Cornea 2001; 20: 164-167.
11 Sjö NC, von Buchwald C, Prause JU, Norrild B, Vinding T, Heegaard S. Human papillomavirus and pterygium. Is the virus a risk factor? Br J Ophthalmol 2007; 91: 1016-1018.

12 Dushku N, Hatcher SL, Albert DM, Reid TW. p53 expression and relation to human papillomavirus infection in pingueculae, pterygia, and limbal tumors. Arch Ophthalmol 1999; 117: 1593-1599.

13 Clavel C, Masure M, Bory JP, Putaud I, Mangeonjean C, Lorenzato $\mathrm{M}$ et al. Human papillomavirus testing in primary screening for the detection of high-grade cervical lesions: a study of 7932 women. Br J Cancer 2001; 84: 1616-1623.

14 Yamazaki H, Sasagawa T, Basha W, Segawa T, Inoue M. Hybrid capture-II and LCR-E7 PCR assays for HPV typing in cervical cytologic samples. Int J Cancer 2001; 94: 222-227.

15 Lorincz AT, Castle PE, Sherman ME, Scott DR, Glass AG, Wacholder $\mathrm{S}$ et al. Viral load of human papillomavirus and risk of CIN3 or cervical cancer. Lancet 2002; 360: 228-229.

16 Healey SM, Aronson KJ, Mao Y, Schlecht NF, Mery LS, Ferenczy A et al. Oncogenic human papillomavirus infection and cervical lesions in aboriginal women of Nunavut, Canada. Sex Transm Dis 2001; 28: 694-700.

17 de Roda Husman AM, Walboomers JM, van den Brule AJ, Meijer CJ, Snijders PJ. The use of general primers GP5 and GP6 elongated at their $3^{\prime}$ ends with adjacent highly conserved sequences improves human papillomavirus detection by PCR. J Gen Virol 1995; 76: 1057-1062.

18 Peyton CL, Schiffman M, Lorincz AT, Hunt WC, Mielzynska I, Bratti C et al. Comparison of PCR- and hybrid capturebased human papillomavirus detection systems using multiple cervical specimen collection strategies. J Clin Microbiol 1998; 36: 3248-3254.

19 Saegusa M, Takano Y, Hashimura M, Okayasu I, Shiga J. HPV type 16 in conjunctival and junctional papilloma, dysplasia, and squamous cell carcinoma. J Clin Pathol 1995; 48: 1106-1110.

20 McDonnell PJ, McDonnell JM, Kessis T, Green WR, Shah KV. Detection of human papillomavirus type 6/11 DNA in conjunctival papillomas by in situ hybridization with radioactive probes. Hum Pathol 1987; 18: 1115-1119. 